\title{
Efektifitas Fototerapi Ganda dan Fototerapi Tunggal dengan Tirai Pemantul Sinar pada Neonatus yang Mengalami Jaundice
}

Emil Azlin

Departemen Ilmu Kesehatan Anak Fakultas Kedokteran Universitas Sumatera Utara/RSUP H.Adam Malik, Medan

Latar belakang. Fototerapi telah dilakukan selama hampir 40 tahun, namun masih ada hal yang diperdebatkan tentang bukti bagaimana fototerapi paling efektif. Fototerapi dengan menggunakan tirai putih pemantul sinar yang diletakkan di sisi-sisi unit fototerapi akan meningkatkan intensitas sinar dan meningkatkan respon penurunan konsentrasi bilirubin serum. Fototerapi ganda lebih efektif daripada fototerapi tunggal pada bayi dengan berat badan lahir rendah dan lebih berguna untuk menurunkan kadar bilirubin serum yang meningkat cepat jika dibandingkan fototerapi tunggal.

Tujuan. Membandingkan efektifitas fototerapi tunggal yang menggunakan tirai putih pemantul sinar dengan fototerapi ganda dalam menurunkan kadar bilirubin.

Metode. Uji klinis acak terbuka, terhadap neonatus cukup bulan yang menderita jaundice pada minggu pertama kehidupan dilakukan di RS. H. Adam Malik dan RS. Dr. Pirngadi Medan pada Mei sampai dengan Desember 2099.

Hasil. Fototerapi dengan menggunakan tirai putih pemantul sinar di sisi-sisi unit fototerapi (kelompok studi, $\mathrm{n}=30$ ) dibandingkan dengan fototerapi ganda (kelompok kontrol, $\mathrm{n}=30$ ). Pengukuran utama adalah nilai ratarata perbedaan penurunan kadar total bilirubin serum dan intensitas sinar pada pengukuran awal sebelum fototerapi, dan 24 jam fototerapi. Selama waktu studi, intensitas sinar pada fototerapi ganda lebih tinggi secara bermakna dibandingkan fototerapi dengan mengggunakan tirai putih pemantul sinar di sekeliling fototerapi $(p<0,05)$. Rerata penurunan kadar total bilirubin serum setelah 24 jam fototerapi lebih tinggi $(p<0,05)$ pada kelompok fototerapi ganda $(10,0 \mathrm{mg} / \mathrm{dl})$ dari pada kelompok fototerapi dengan tirai $(7,4 \mathrm{mg} / \mathrm{dL})$.

Kesimpulan. Penggunakan fototerapi ganda lebih efektif dalam menurunkan kadar bilirubin dibandingkan dengan fototerapi tunggal dengan menggunakan tirai putih di sekeliling unit fototerapi. Sari Pediatri 2011;13(2):111-6.

Kata kunci: jaundice, fototerapi ganda, tirai putih pemantul sinar, hiperbilirubinemia, neonatus

\begin{abstract}
Alamat korespondensi:
Dr. Emil Azlin, Sp.A. Departemen Ilmu Kesehatan Anak Fakultas Kedokteran Universitas Sumatera Utara/ RSUP H.Adam Malik Jl. Bunga Lau no.17 Medan. Tel. 061-8361721 - 061-8365663 Fax. (061) 8361721 E-mail: bikafkusu@telkom.net; kotak Pos 697 Medan $-20136$.
\end{abstract}

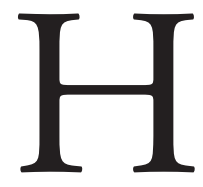

iperbilirubinemia adalah terjadinya peningkatan kadar plasma bilirubin $\geq 2$ standar deviasi berdasarkan usia bayi atau $\geq$ persentil $90 .^{1-3}$ Angka kejadian 
hiperbilirubinemia pada bayi baru lahir cukup tinggi pada neonatus cukup bulan sekitar 25\% sampai 50\% dan sekitar $6,1 \%$ di antaranya akan mencapai kadar bilirubin $12,9 \mathrm{mg} / \mathrm{dl}$, sedangkan kadar bilirubin lebih dari $15 \mathrm{mg} / \mathrm{dL}$ mencapai 3\% dari total neonatus cukup bulan. ${ }^{4-6}$ Angka kejadian hiperbilirubinemia lebih tinggi pada neonatus kurang bulan. ${ }^{7-8}$

Fototerapi merupakan modalitas terapi dengan menggunakan sinar yang dapat dilihat untuk pengobatan hiperbilirubinemia pada neonatus. Di Amerika Serikat sekitar $10 \%$ neonatus mendapat fototerapi. ${ }^{9-}$

${ }_{14}$ Tujuan fototerapi untuk membatasi peningkatan bilirubin serum dan mencegah penumpukan bilirubin di jaringan otak yang dapat menyebabkan komplikasi neurologis yang dikenal sebagai kernicterus. ${ }^{1-7}$ Efektifitas fototerapi ditentukan oleh intensitas sinar, penurunan kadar bilirubin sebanding dengan intensitas sinar yang digunakan. ${ }^{9-11}$ Penggunaan tirai putih pemantul sinar dapat meningkatkan intensitas sinar fototerapi sehingga dapat meningkatkan efektifitas fototerapi. Hal tersebut bermanfaat di negara-negara berkembang karena dapat menghemat biaya dan memperpendek masa rawat. ${ }^{15-16}$ Beberapa studi mencoba meningkatkan intensitas sinar pada fototerapi dengan fototerapi ganda yang menghasilkan penurunan bilirubin lebih cepat dibanding fototerapi tunggal. ${ }^{17-18} \mathrm{Hal}$ ini disebabkan iradiasi spektrum yang lebih tinggi dan lebih luas permukaan tubuh yang terpapar pada fototerapi ganda. Model fototerapi ganda disebut juga sebagai fototerapi intensif yang diberikan pada neonatus yang mengalami peningkatan bilirubin serum yang sangat cepat, ${ }^{19-22}$ seperti yang sering terjadi pada pada bayi berat lahir rendah. ${ }^{23-24}$

Studi mengenai efektifitas fototerapi standar dengan memakai tirai pemantul sinar dan fototerapi ganda telah banyak dipublikasikan. ${ }^{15-23}$ Namun belum ada studi yang membandingkan efektifitas dari kedua fototerapi. Penelitian bertujuan untuk membandingkan penurunan bilirubin pada fototerapi tunggal yang menggunakan tirai putih pemantul sinar dengan fototerapi ganda.

\section{Metode}

Penelitian merupakan uji klinis acak terbuka untuk membandingkan penurunan bilirubin pada fototerapi tunggal menggunakan tirai putih pemantul sinar dengan fototerapi ganda. Penelitian dilakukan di Unit
Perinatologi RS. H.Adam Malik dan RS. Pirngadi di Medan. Penelitian dilaksanakan, mulai Mei - Desember 2009. Populasi target adalah bayi cukup bulan yang mengalami hiperbilirubinemia indirek. Sampel adalah populasi terjangkau yang memenuhi kriteria inklusi. Jumlah sampel untuk masing-masing kelompok adalah 30 neonatus. Kriteria inklusi adalah bayi baru lahir usia $>24$ jam tetapi $<28$ hari, neonatus yang menderita hiperbilirubinemia sesuai kriteria AAP, neonatus cukup bulan sesuai masa kehamilan, dan mendapat izin orangtua secara tertulis. Kriteria eksklusi adalah neonatus yang menderita hiperbilirubinemia direk, neonatus dengan kadar bilirubin indikasi dilakukan transfusi tukar, neonatus yang menderita penyakit hemolitik, neonatus menderita kelainan kongenital.

\section{Cara Kerja}

Neonatus yang sesuai dengan kriteria inklusi diambil darah kapiler untuk pemeriksaan darah rutin, tes Coombs, retikulosit, bilirubin total, dan bilirubin direk. Kemudian dilakukan randomisasi sederhana menggunakan amplop tertutup dan membagi sampel menjadi dua kelompok yaitu kelompok A adalah neonatus yang mendapat fototerapi ganda dengan jarak $40 \mathrm{~cm}$ dari neonatus menggunakan unit fototerapi standar merk Tessna berisikan 5 buah lampu sinar biru merk Toshiba dengan panjang gelombang 425-475 $\mathrm{nm}$ dengan posisi paralel. Kelompok B mendapat fototerapi tunggal dengan jarak dan unit fototerapi yang sama ditambah kain dan plastik putih pemantul sinar yang diletakkan di sisi kiri, kanan dan belakang neonatus dengan susunan kain di luar dan plastik di dalam. Neonatus diperiksa kadar bilirubin awal dan 24 jam serta diperiksa temperatur, berat badan dan tanda-tanda dehidrasi secara berkala. Neonatus diberi penambahan cairan $10 \%$ dari total kebutuhan cairannya secara oral atau intravena. Bayi juga diberi penutup mata. Fototerapi dihentikan bila bilirubin sudah mencapai kadar normal atau ditemukan efek samping seperti hipertermia, dehidrasi, kelainan kulit, letargi dan iritabilitas.

\section{Analisis data}

Untuk melihat penurunan kadar bilirubin sebelum fototerapi dan 24 jam fototerapi digunakan uji t- 
berpasangan untuk masing-masing kelompok. Untuk melihat perbedaan intensitas sinar pada awal, dan 24 jam fototerapi digunakan the Mann-Whitney $U$ test. Disebut bermakna secara statistik bila $p<0,05$ dengan IK 95\%. Data diolah dan dianalisis dengan menggunakan program SPSS for Windows 14.0

\section{Hasil}

Selama periode penelitian terdapat 72 neonatus yang menderita hiperbilirubinemia dan dieksklusikan sebanyak 9 neonatus (4 neonatus menderita hiperbilirubinemia direk, 3 neonatus menderita kelainan congenital, dan 2 neonatus tidak mendapat izin orang tua). Sehingga terdapat 63 neonatus yang memenuhi kriteria inklusi, 2 drop out dari penelitian karena sampel darah rusak dan 1 neonatus meninggal sebelum pengambilan darah. Besar sampel pada kedua kelompok sama masing-masing 30 neonatus (Gambar $1)$.

Data awal subjek memperlihatkan karakteristik yang sama seperti jenis kelamin, jumlah bayi laki-laki sama banyak dengan jumlah perempuan pada kedua kelompok yaitu 15, usia pada saat dilakukan fototerapi rata-rata pada saat berusia 5 hari baik pada kelompok fototerapi dengan tirai maupun kelompok fototerapi ganda. Bilirubin awal sebelum dilakukan fototerapi pada kelompok fototerapi dengan tirai rata-rata $18,6 \mathrm{mg} / \mathrm{dL}$ lebih tinggi bila dibandingkan dengan kelompok fototerapi ganda yaitu $17,5 \mathrm{mg} / \mathrm{dL}$. Berat badan untuk kedua kelompok rata-rata 2700 gram. Kadar albumin pada kedua kelompok memiliki kadar yang rendah, pada kelompok fototerapi dengan tirai 2,9 g/dL dan pada kelompok fototerapi ganda 2,6 g/ dL. Kadar hemoglobin di kedua kelompok adalah sama yaitu $14 \mathrm{~g} / \mathrm{dL}$ (Tabel 1).

Pada pengukuran intensitas sinar pada awal penelitian, 12 jam, dan 24 jam fototerapi didapati perbedaan yang bermakna pada intensitas sinar dengan fototerapi ganda dibanding dengan fototerapi tunggal yang menggunakan tirai pemantul sinar. Nilai $p=0,0001,(p<0,05)$ di awal dan 24 jam fototerapi (Gambar 2).

Pada pengukuran kadar bilirubin setelah 12 jam dan 24 jam fototerapi, didapati perbedaan yang bermakna terhadap penurunan kadar bilirubin pada kelompok yang mendapat fototerapi ganda dibanding

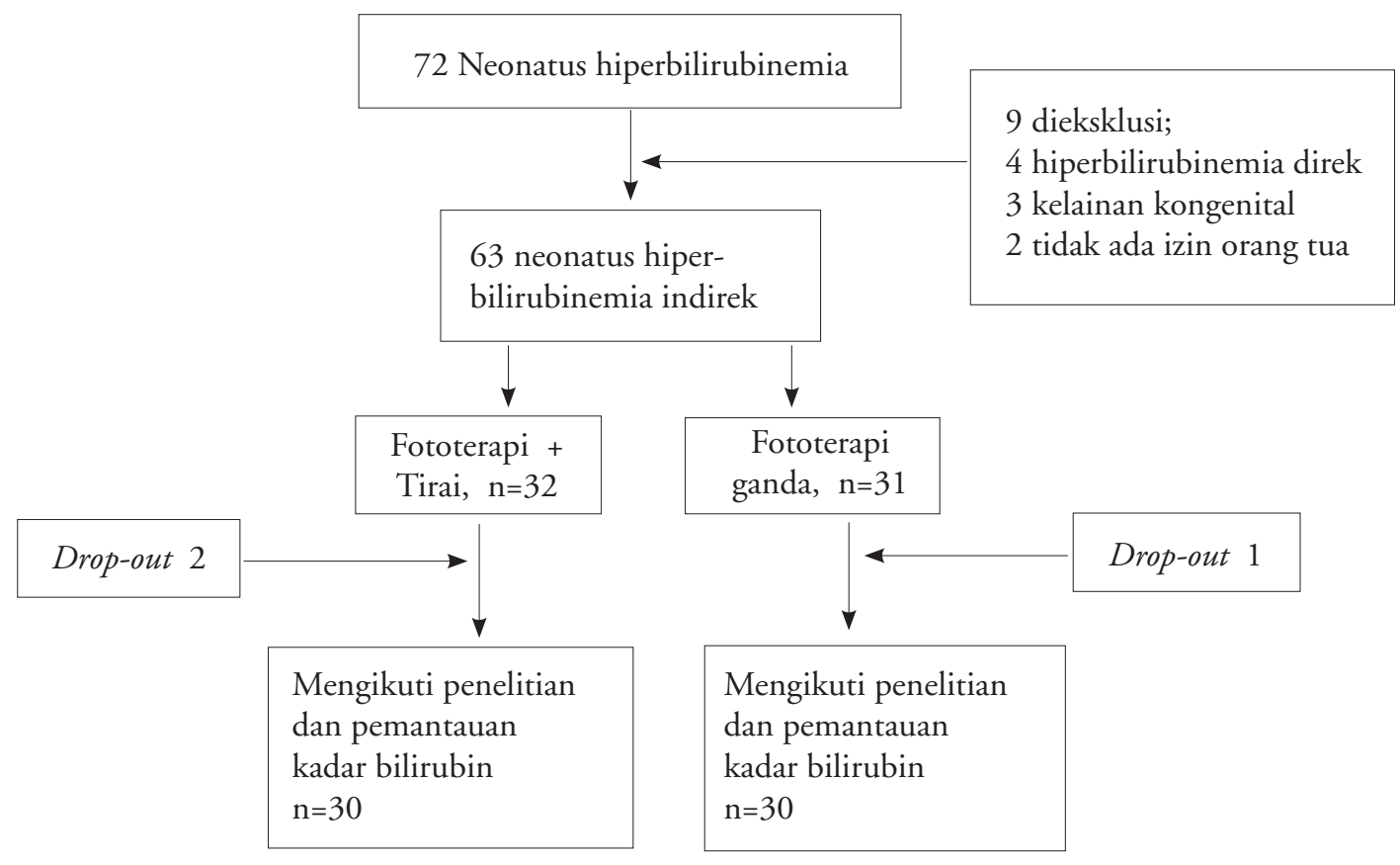

Gambar 1. Rekrutmen subjek penelitian 
Tabel 1. Data karakteristik subjek

\begin{tabular}{lcc}
\hline Karakteristik & $\begin{array}{c}\text { Fototerapi dengan tirai } \\
(\mathrm{n}=30)\end{array}$ & $\begin{array}{c}\text { Fototerapi ganda } \\
(\mathrm{n}=30)\end{array}$ \\
\hline Jenis kelamin (laki laki/perempuan) & $15 / 15$ & $16 / 14$ \\
Usia saat mendapat fototerapi (hari, rerata, SB) & $5,0(1,36)$ & $5,0(1,35)$ \\
Berat badan (gram, rerata, SB) & $2761(203,7)$ & $2673(149,5)$ \\
Temperatur $\left({ }^{\circ} \mathrm{C}\right.$, rerata, SB) & $6,9(0,3)$ & $36,8(0,30)$ \\
Kadar bilirubin awal (mg/dL, rerata, SB) & $18,6(1,8)$ & $17,5(1,34)$ \\
Albumin $(\mathrm{g} / \mathrm{dL}$, rerata, SB) & $2,9(0,2)$ & $2,6(0,18)$ \\
Hemoglobin $(\mathrm{g} / \mathrm{dL}$, rerata, SB) & $14,0(1,7)$ & $14,0(1,49)$ \\
\hline
\end{tabular}

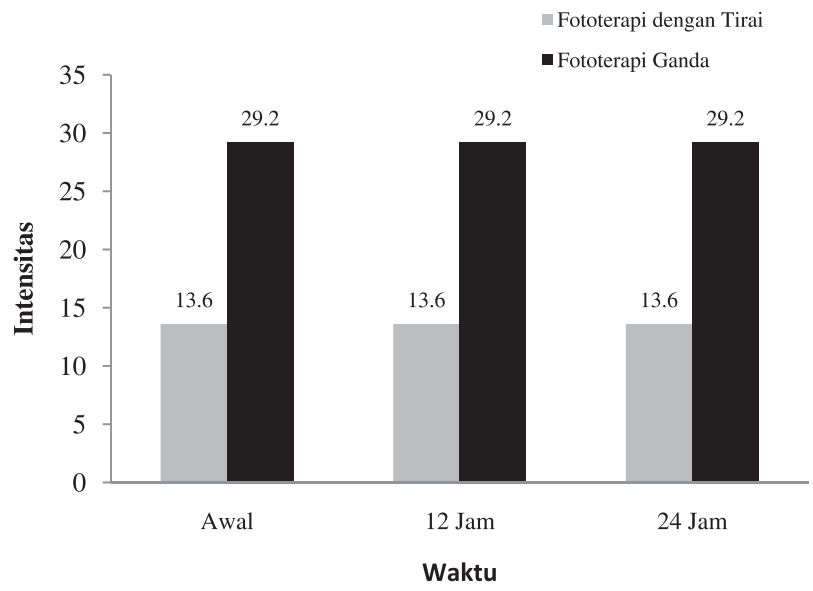

Gambar 2. Intensitas sinar awal, 12 dan 24 jam fototerapi

dengan kelompok fototerapi tunggal memakai tirai pemantul sinar dengan nilai $p=0,0001$ (Tabel 2). yang dilakukan di Kelantan, Malaysia memberikan hasil peningkatan intensitas sinar yang signifikan pada fototerapi tunggal menggunakan tirai putih pemantul sinar dibanding dengan fototerapi tunggal tanpa tirai. ${ }^{15-16}$

Fototerapi ganda dengan menggunakan sinar biru (panjang gelombang 430-490 nm) dengan intensitas $\geq 30 \mathrm{uW} / \mathrm{cm}^{2}$ (diperiksa dengan radiometer, atau diperkirakan dengan menempatkan bayi langsung di bawah sumber sinar dan kulit bayi yang terpajan lebih luas) sangat efektif menurunkan kadar bilirubin., ${ }^{2,3}$ Hal ini dapat menyebabkan peningkatan produksi lumirubin dan intensitas sinar. ${ }^{25-27}$ Pada penelitian kami didapati perbedaan intensitas sinar yang signifikan pada fototerapi menggunakan tirai dengan fototerapi ganda di awal, 12 jam dan 24 jam fototerapi.

Intensitas sinar yang dihasilkan dari fototerapi ganda lebih dari dua kali lipat intensitas sinar yang dihasilkan

Tabel 2. Penurunan kadar bilirubin pada awal, 12 jam dan 24 jam fototerapi

\begin{tabular}{lcccc}
\hline Kadar bilirubin & $\begin{array}{c}\text { Fototerapi Tirai } \\
\text { Rerata (SB) }\end{array}$ & $\begin{array}{c}\text { Fototerapi Ganda } \\
\text { Rerata (SB) }\end{array}$ & IK 95\% & $p$ \\
\hline Bilirubin awal & $18,7(1,81)$ & $17,5(1,34)$ & 0,$06 ; 1,76$ & 0,38 \\
Bilirubin 12 jam & $14,9(1,98)$ & $11,0(1,39)$ & 2,$98 ; 4,75$ & 0,0001 \\
Bilirubin 24 jam & $9,0(2,24)$ & $4,0(1,35)$ & 3,$54 ; 4,55$ & 0,0001 \\
\hline
\end{tabular}

\section{Pembahasan}

Intensitas yang dicapai menentukan efektivitas fototerapi, semakin tinggi intensitas sinar maka semakin cepat penurunan kadar bilirubin serum..$^{9-11}$ Intensitas sinar lebih tinggi pada fototerapi menggunakan tirai putih dari pada tanpa menggunakan tirai. Penelitian pada fototerapi yang menggunakan tirai putih pemantul sinar. Pengukuran intensitas sinar dilakukan pada awal, 12, dan 24 jam fototerapi yang bertujuan untuk memastikan bahwa tidak terjadi penurunan intensitas sinar setelah 12 atau 24 jam fototerapi.

Penelitian uji klinis acak di Thailand mendapatkan fototerapi ganda lebih aman dan efektif menurunkan 
kadar bilirubin dibandingkan fototerapi tunggal. Fototerapi ganda merupakan model alternatif untuk fototerapi intensif yang sangat efektif, ekonomis dan mudah digunakan. ${ }^{28-29}$ Hasil yang sama dijumpai pada penelitian yang dilakukan di Amerika dengan menggunakan fototerapi ganda terbukti lebih aman dan efektif dalam menurunkan kadar bilirubin dibandingkan fototerapi tunggal dan selama penelitian tidak dijumpai efek samping. ${ }^{30}$

Didapatkan pola penurunan kadar bilirubin yang bermakna setelah fototerapi selama 12 dan 24 jam pada kelompok fototerapi ganda dibandingkan dengan kelompok fototerapi tunggal yang menggunakan tirai. Namun penurunan kadar bilirubin pada kelompok fototerapi ganda tidak sebanding dengan intensitas sinar yang dihasilkan yang mencapai lebih dari dua kali lipat intensitas sinar kelompok fototerapi yang menggunakan tirai putih pemantul sinar.

\section{Kesimpulan}

Fototerapi ganda menghasilkan intensitas sinar yang lebih besar dan lebih efektif dalam menurunkan kadar bilirubin pada neonatus yang mengalami hiperbilirubinemia indirek dibanding fototerapi tunggal yang menggunakan tirai putih pemantul sinar. Perlu penelitian lebih lanjut pada neonatus yang mengalami hiperbilirubunemia dengan subjek yang lebih banyak dan kadar bilirubin yang lebih tinggi.

\section{Daftar pustaka}

1. Sukadi A. Hiperbilirubinemia. Dalam: Kosim MS, Yunanto A, Dewi R, Sarosa GI, Usman A, penyunting. Buku ajar neonatologi. Edisi 1. Jakarta: IDAI; 2008.h.14769.

2. Martiza L. Ikterus. Dalam: Juffrie M, Oswari H, Arief S, Rosalina I,, penyunting. Buku ajar gastroenterologihepatologi. Jilid I. Jakarta. Badan Penerbit IDAI; 2010.h. 263-84.

3. Kaplan M, Muraca M, Hammerman C, Rubaltelli FF, T Maria. Imbalance between production and conjugation of bilirubin: A fundamental concept in the mechanism of neonatal jaundice 2002;13:110.

4. Martin CR, Cloherty JP. Neonatal hyperbilirubinemia. Dalam: Cloherty JP, Eichenwald EC, Stark AR, penyunting. Manual of neonatal care. Edisi ke-5.
Philadelphia: Lippincot, Williams \& Wilkins; 2004.h.185-219.

5. Gomella TL, penyunting Hyperbilirubinemia indirect. Dalam: Neonatology: management, procedures, on-call problem, disease, and drugs. Edisi ke-5. New York: The McGraw-Hill companies, Inc; 2004.h.247-50.

6. Dennery AP, Seidman DM, Stevenson KD. Neonatal hyperbilirubinemia. N Engl J Med. 2001;8:581-90.

7. Hammerman C,Kaplan M. Recent developments in the management of neonatal hyperbilirubinemia. Neo Reviews 2000;1:19.

8. Stoll BJ, Kliegman RM. Jaundice and hyperbilirubinemia in the newborn. Dalam: Behrman RE, Kliegman RM, Jenson HB, penyunting. Nelson textbook of pediatrics. Edisi ke 17. Philadelphia: Elsevier Saunders; 2006.h. 592-8.

9. Bagchi A. Phototherapy. Dalam: MacDonald MG, Ramasethu, penyunting Procedures in neonatology. Edisi ke-3. Philadelphia: William Wilkins; 2002.h. 373-8.

10. Subcommitee on hyperbilirubinemia. American Academy of Pediatrics. Management of hyperbilirubinemia in the newborn infant 35 or more weeks of gestation. Pediatrics 2004; 114:297-316

11. Canadian Paediatric Society. Guidelines for detection, management and prevention of hyperbilirubinemia in term and late preterm newborn infants (35 or more weeks' gestation). Paediatr Child Health 2007;12:1-13

12. Sarici SU, Serdar MA, Korkmaz A, Erdem G, Oran. Incidence, course and prediction of hyperbilirubinemia in near-term and term newborn. Pediatrics 2004; 113:775-80.

13. Madan A, Macmahon JR, Stevenson DK. Neonatal hiperbilirubinemia. Dalam: Taeusch HW, Ballard RA, Gleason CA, penyunting. Avery's disease of the newborn. Edisi ke-8. Philadelphia: Elsevier Saundersr;2005.h.122653.

14. Erika R, Harianto A, Indarso F, Damanik M.S. Hiperbilirubinemia pada neonatus. Diunduh dari: www.pediatrik. com/pkb/20060220-js9. Diakses tgl 20 November 2008

15. Djokomulyanto S, Quah BS, Surini Y, Noraida R, Ismail NZN, Hansen TWR, dkk. Efficacy of phototherapy for neonatal jaundice is increased by the use of low-cost white reflecting curtains. Arch Dis Child Fetal Neonatal 2006;91: 4212-439.

16. Sivanandan S, Chawla D, Misra S, Agarwal R, Deorari AK. Effect of Sling Application on Efficacy of Phototherapy in Healthy Term Neonates with Nonhemolytic Jaundice: A ranndomized Conrolled Trial. Indian pediatrics $2009 ; 46: 23-8$ 
17. Sarici SU, Alpay F, Unay B, Ozcan O, Gokcay E. Double versus single phototherapy in term newborn with significant hyperbilirubinemia. J Trop Pediatrics 2000;46:36-9.

18. Sarin M, Dutta S, Narang A. Randomized controlled trial of compact fluorescent lamp versus standard phototherapy for the treatment of neonatal hyperbilirubinemia. Indian Pediatr 2006;43:583-90.

19. Hosono S, Ohno T, Kimoto H, Nagoshi R, Shimizu M, Nozawa M. Effects of albumin infusion therapy on total and unbound bilirubin values in term infants with intensive phototherapy. Pediatrics International 2001;43:8-11.

20. Shahian M, Moslehi MA. Effect of albumin administration prior to exchange transfusion in term neonates with hyperbilirubinemia a randomized controlled trial. Published Online 2009; 47: 231-2

21. Facchini FP, Bianchi MO, Silva BA. Intensive phototherapy treatment for severe haemolytic disease of the newborn. J Pediatr (Rio J) 2000;76:387-90.

22. Newman TB, Liljestrand P, Escobar GJ. Infants with bilirubin levels of $30 \mathrm{mg} / \mathrm{dL}$ or more in a large managed care organization. Pediatrics 2003;111:1303-11.

23. Holtrop PC, Ruedisueli K, Maisels MJ. Double versus single phototherapy in low birth weight newborns.
Pediatrics 2008;90:674-7.

24. Morris BH, Oh W, Tyson JE, Stevenson DK, Phelps DL. Aggressive vs.conservative phototherapy for infants with extremely low birth weight. N Engl J Med 2008;359:1885-96.

25. Hart G, Cameron R. The importance of irradiance and area in neonatal phototherapy. Arch Dis Child Fetal Neonatal 2005;90:437-40.

26. Maisels MJ, Donagh FA. Phototherapy for neonatal jaundice. N Engl J M 2008;358:920-8

27. Hansen TWR. Phototherapy for neonatal jaundicetherapy effects on more than one level?. Semin Perinatol 2010;34:231-4.

28. Nuntnarumit P, Naka C. Comparison of the effectiveness between the adapted double phototherapy versus conventional-single phototherapy. J Med Assoc Thai 2002;85:1159-66.

29. Boonyarittipong P, Kriangburapa W, Booranavanich K. Effectiveness of double- surface intensive phototherapy versus single-surface intensive phototherapy for neonatal hyperbilirubinemia.J Assoc Thai 2008;90:50-5.

30. Silva I, Luco M, Tapia JL, Perez ME, Salinas JA, Flores J. Single vs. double phototherapy in the treatment of fullterm newborns with non hemolytic hyperbilirubinemia. J Pediatr (Rio J) 2009;85:455-8. 